\title{
Caracterização espacial da migração de retorno ao Nordeste: uma análise dos fluxos migratórios intermunicipais nos quinquênios 1995- 2000 e 2005-2010
}

\author{
Jarvis Campos ${ }^{1}$ \\ Cristiano S. dos Reis ${ }^{2}$ \\ Douglas Sathler ${ }^{3}$
}

Palavras chave:Migração de Retorno; Migração de Retorno inter-regional; Fluxos migratórios; Fluxos migratórios inter-regionais; Naturalidade da Migração; Hierarquia de Cidades

\footnotetext{
1 Doutorando em Demografia pelo Centro de Desenvolvimento e Planejamento Regional (CEDEPLAR/UFMG).

2 Doutorando em Demografia pelo Centro de Desenvolvimento e Planejamento Regional (CEDEPLAR/UFMG).

${ }^{3}$ Professor adjunto da Universidade Federal do Vale do Jequitinhonha e Mucuri (UFVJM).
} 


\section{Introdução}

Importantes transformações na história migratória brasileira aconteceram na década de 1980, especialmente no que tange às tendências de redistribuição espacial da população. Concomitante à redução drástica de certos fluxos migratórios para o Sudeste ou para as áreas de fronteira, pôde-se identificar a intensificação dos movimentos de retorno, processo este que configura a nova realidade da dinâmica de redistribuição populacional do país. No caso do Nordeste, os nove estados que o compõem vêm apresentando uma recuperação dos saldos migratórios negativos observados em décadas anteriores, seja em função da redução da emigração, seja devido ao crescimento da imigração, em parte caracterizada pela migração de retorno (CUNHA E BAENINGER, 2001).

O migrante, ao sair do local de origem, poderá escolher entre duas alternativas: ou fixa definitivamente (o que representaria um processo de inserção no destino), ou regressa à sociedade de origem (num contexto de reinserção). Fazito (2005) afirma que o ciclo vital da migração se fecha no retorno à terra natal, pois o retorno constitui um princípio simbólico que inscreve a circularidade nas migrações. Desta forma, os sistemas empíricos de migração comportam como etapa essencial o retorno, que a um só tempo fundamenta simbolicamente todo e qualquer deslocamento, além de desempenhar uma função estrutural na topologia desses sistemas, dado que dinamiza o processo migratório.

Além disso, é importante considerar fatores relacionados com as escolhas individuais envolvidas no processo do retorno. Geralmente, o motivo principal da saída do indivíduo é de ordem econômica, ou seja, o indivíduo emigra em busca de melhores oportunidades de emprego na expectativa de incrementar sua renda. Entretanto, o retorno muitas vezes se verifica por algum equívoco de avaliação quanto às oportunidades no local de destino, o que resulta em frustração no que tange às suas expectativas quanto às melhorias almejadas. Porém, a migração pode fazer parte ainda de um planejamento em longo prazo de mudança de residência. Assim, primeiro o migrante se posiciona como um trabalhador que acrescentará bens e/ou benefícios no tempo de sua estada fora, para depois, mais idoso, retornar para seu local de origem e, dessa maneira, desfrutar a velhice juntamente com seus familiares (COSTA \& RIGOTTI, 2008). 
No processo migratório, ter contato com uma cultura diferente, uma diversidade de pessoas, hábitos e ambientes distintos, é sempre positivo para o desenvolvimento pessoal. Não obstante, as habilidades adquiridas muitas vezes podem vir a se tornar em limitações à reinserção dos retornados nas suas comunidades de origem, e servem também para potencializar conflitos entre estes e os não-migrantes (inclusive dentro da família, como no caso das relações de gênero entre casais) (FAZITO, 2005).

Dessa forma, nem as habilidades adquiridas nem o dinheiro poupado parecem cumprir papel definitivo na reinserção dos retornados nas comunidades de origem (FAZITO, 2005). Portanto, pode-se afirmar que o retorno não ocorre pura e simplesmente por um "sucesso" ou um "fracasso" econômico no mercado de trabalho de destino, mas também se relaciona como próprio ciclo de vida dos migrantes.

$\mathrm{Na}$ perspectiva das técnicas de mensuração, pesquisas feitas no Brasil (RIBEIRO, 1997; GARCIA E MIRANDA-RIBEIRO, 2005) mostram que as migrações de retorno têm grande impacto sobre o volume total das migrações, contribuindo definitivamente para o fortalecimento e expansão dos seus fluxos (FAZITO, 2005). Dados do Censo de 1970 mostram que os fluxos de retorno representavam $11 \%$ da migração no Brasil, ao passo que, entre 1980-1991, este percentual aumentou para 24,5\% (BAENINGER, 2000).

Os dados censitários de 2000 revelam que no Brasil, 1.129.694 indivíduos decidiram regressar aos seus estados de origem entre os anos de 1995-2000. Número considerável, já que representa $21,7 \%$ do total de pessoas que fizeram algum deslocamento nesse período. Quando se observa os dados do Censo de 2010, nota-se uma pequena queda no número total e relativo de migrantes retornados no país. Entre os anos 2005-2010, o número de migrantes retornados era de 999.662 indivíduos ou 21,5\% do total de deslocamentos no país (SIQUEIRA, MAGALHÃES E SILVEIRA NETO, 2008; BAPTISTA, CAMPOS E RIGOTTI, 2012).

Neste contexto, o Nordeste vem se destacando como a região de maior proporção de retornados interestaduais. No período 1995-2000, 43,5\% do total de imigrantes do Nordeste foram de retorno, com destaque para os Estados da Paraíba $(49,2 \%)$, Ceará $(48,2 \%)$ e Piauí $(46,2 \%)$. Por outro lado, no quinquênio 2005-2010 houve uma redução na proporção relativa dos migrantes retornados para o Nordeste (37,5\%), com destaque para o Ceará $(43,6 \%)$, seguidos da Paraíba $(40,8 \%)$ e Piauí $(38,9 \%)$ (BAPTISTA, CAMPOS E RIGOTTI, 2012). Essa ligeira queda entre os quinquênios 1995-2000 e 2005-2010 pode ser explicada pela redução geral das 
migrações observadas entre os censos 2000 e 2010. Apesar disso, estes dados mostram a importância da migração de retorno dentro do fenômeno migratório.

Diante à relevância do tema, o presente trabalho tem como objetivo analisar o volume e os fluxos migratórios de retorno de data fixa nos quinquênios 1995-2000 e 2005-2010 para os municípios do Nordeste, e com origem nos municípios fora da Região Nordeste, que por sua vez representam grande parte do volume da migração de retorno, observado nas últimas décadas (BRITO, RIGOTTI E CAMPOS, 2012). Pretende-se, portanto, aprofundar os conhecimentos acerca do padrão da distribuição espacial (ou dos fluxos) dessa parcela de migrantes; contribuindo, assim, para uma maior compreensão desse importante eixo de migração, fundamental na dinâmica migratória brasileira. Além da migração de retorno, serão considerados a naturalidade do retornado bem como o tamanho do município de destino.

Nesse contexto, o estudo pretende responder as seguintes perguntas: no nível municipal, quais os principais eixos de migração? Há uma concentração do migrante de retorno ao próprio município de nascimento? Ou a maioria dos migrantes retornados tem como destino outros municípios da Unidade da Federação de nascimento? As cidades de destino da migração de retorno seriam de pequeno, médio ou de grande porte?

O trabalho está dividido em quatro seções. A segunda seção discorre sobre a metodologia e a base de dados. Na terceira seção são apresentados e discutidos os resultados, enquanto a última seção são as conclusões.

\section{Metodologia e fonte de dados}

O objetivo do trabalho é analisar os fluxos migratórios quinquenais, no nível dos municípios, tendo como destino os municípios do Nordeste e a origem os demais municípios do Brasil (exceto a própria região Nordeste), e ainda subdivido por duas categorias: a) os retornados para o próprio município de nascimento; e os retornados para a Unidade da Federação de nascimento, mas não para o próprio município; b) e esses dois tipos de retorno representados por uma categoria de municípios de destino, definida através de uma hierarquia de tamanho populacional (definida em cinco níveis). Para tanto, foram utilizados dados dos Censos de 2000 e 2010, a partir do conceito de migrante de retorno de data fixa, para os quinquênios 1995-2000 e 2005-2010. 
A hierarquia dos municípios de destino (dos retornados) foi definida a partir do critério de tamanho populacional. Os dois tipos de retorno já comentado (para o próprio município ou para a própria UF) foram desagregados a partir das seguintes categorias: municípios menores de 50.000 habitantes; entre 50.000 e 100.000 habitantes; entre 100.000 e 500.000 habitantes; entre 500.000 e 1 milhão de habitantes; e cidades com mais de 1.000.000 de habitantes.

A definição da hierarquia de cidades, através do tamanho do populacional, teve como objetivo a obtenção de uma Proxy para a distinção entre áreas mais dinâmicas (com maiores oportunidades de trabalho, bem como maior infraestrutura urbana e de serviços, de um modo geral) e que corresponderiam, por hipótese, às cidades de médio e grande porte populacional; e áreas estagnadas (como é o caso dos municípios do interior nordestino, marcados pela seca, pobreza e perdas líquidas de população), e que correspondem, por sua vez, a municípios de pequeno contingente populacional.

$\mathrm{Na}$ etapa de construção dos dados, foram criados dois bancos de dados (referentes aos Censos de 2000 e 2010) com todos os fluxos intermunicipais, tendo como destino os 1.794 municípios da Região Nordeste, e origem os 3.771 municípios das demais Grandes Regiões do Brasil. Esses bancos de dados foram ainda subdivididos conforme a naturalidade da migração de retorno e a hierarquia dos municípios, como ressaltado anteriormente. O grande volume de informações tornou inviável a utilização de softwares estatísticos convencionais, que são limitados ao tratamento de grandes bancos de dados. Diante disso, foi utilizado o Sistema de Gerenciamento de Banco de Dados (SGBD) Postgree SQL, para a criação e organização dos dados, e o PostGis (extensão espacial do Postgree) para a conexão do banco de dados com o QGIS (Sistema de Informação Geográfica utilizado na etapa de mapeamento). Ressalta-se ainda a utilização da ferramenta Flowmapper (extensão do QGIS) para a elaboração dos fluxos migratórios intermunicipais.

\section{Resultados}

\subsection{Contexto geral da migração de retorno inter-regional no Nordeste}

O Brasil tem experimentado uma redução nas migrações nos últimos anos. Entre os quinquênios 1995-2000 e 2005-2010 houve uma diminuição de 10,6\% nas migrações intermunicipais (de 5.196.087 para 4.643.745), tendência também observada na Região 
Nordeste (11\%, de 1.055 .924 para 939.777). No caso da migração de retorno ${ }^{4}$ ao Nordeste, nota-se uma diminuição ainda maior no volume, reduzindo $23,1 \%$ entre os quinquênios 1995-2000 e 2005-2010 (de 458.959 para 352.738), o que resultou na redução do peso da migração de retorno no total das migrações dessa região para o mesmo período, passando de 43,5\% para 37,5\% (IBGE, 2000; IBGE, 2010). Contudo, a migração de retorno continua sendo um fenômeno importante para a compreensão da dinâmica migratória, em especial na Região Nordeste, onde representa mais de um terço das migrações dessa região no último quinquênio.

A Região Nordeste segue as tendências observadas no Brasil. Ao mesmo tempo em que se verifica a manutenção de antigas trajetórias migratórias, como, por exemplo, a continuidade das perdas líquidas de população no Nordeste - cujas taxas líquidas nos quinquênios 1995-2000 e 2005-2010 foram negativas em, respectivamente, 1,79\% e $1,44 \%$ - tem se observado o crescimento de contra fluxos, como é o caso do aumento do peso relativo da migração de retorno inter-regional ${ }^{5}$ para o Nordeste. No período 1995-2000, 76,2\% da migração de retorno aos estados nordestinos tinham como origem Unidades da Federação fora da Região Nordeste (349.896), enquanto que, no período 2005-2010, essa proporção aumentou para 81,5\% (287.657) [IBGE, 2000; IBGE, 2010].

Diante à importância da migração de retorno inter-regional da Região Nordeste para a compreensão das tendências recentes das migrações no país, este trabalho busca compreender qual o perfil e a dinâmica espacial deste tipo de mobilidade. Assim, são analisados os quinquênios de 1995-2000 e 2005-2010: a naturalidade do retorno interregional, se para o próprio município de nascimento ou se para a Unidade da Federação de nascimento (porém para outro município do Estado); a hierarquia do município de destino, definido através do tamanho populacional; e os fluxos migratórios intermunicipais.

As tabelas 1 e 2 (em anexo) apresentam o perfil da migração de retorno interregional no Nordeste no nível das Unidades da Federação, nos quinquênios 1995-2000 e 2005-2010. A origem das migrações é bastante concentrada, com destaque para o Estado de São Paulo (56,4\% e 46,8\%), seguido pelo Rio de Janeiro (11,8\% e 12,5\%) e Distrito Federal (5,8\% e 7\%), enquanto os demais Estados representam 26\% e 33,7\%,

\footnotetext{
${ }^{4}$ A migração de retorno, neste trabalho, corresponde à migração de retorno de data-fixa; ou seja, os indivíduos que há 5 anos estavam em outro Estado, em relação à Unidade da Federação de nascimento, e, na data de referência retornaram ao Estado de nascimento.

${ }^{5} \mathrm{~A}$ migração de retorno inter-regional, neste trabalho, corresponde à migração de retorno de data-fixa para o Nordeste, mas somente para aqueles que, na data fixa, estavam em Unidades da Federação fora da Região Nordeste.
} 
respectivamente aos dois períodos. Considerando todas as origens, nos dois quinquênios, mais da metade dos migrantes de retorno inter-regionais ao Nordeste têm como destino o próprio município de nascimento $(54,9 \%$ e $61,8 \%)$, tendência em parte definida pelas migrações com origem em São Paulo, cujo retorno ao próprio município de nascimento é de $58,5 \%$ e $63,7 \%$, e com tendência similar o Rio de Janeiro (55,2\% e $64,6 \%)$ e o Distrito Federal (60,2\% e 65\%). É interessante observar que, somente no caso dos outros Estados, a proporção do retorno ao próprio município de nascimento representou menos da metade das migrações de retorno inter-regional de data-fixa no quinquênio 1995-2000 (45,7\%), enquanto que, em 2005-2010, a proporção aumentou para 57,4\%. Observa-se, assim, um aumento do retorno ao próprio município de nascimento entre os dois períodos. Os demais estados, que representam uma "alternativa" aos principais eixos de migração (São Paulo, Rio de Janeiro e Distrito Federal) dão indícios de um padrão migratório diferenciado.

Assim como se observa, no Nordeste, a prevalência da migração de retorno inter-regional para o próprio município de nascimento, a maioria dos retornados têm como destino municípios pequenos, com até 50 mil habitantes $(53,8 \%$ em 2000 e 50,1\% em 2010), o que reflete a importância das perdas populacionais no passado, de áreas estagnadas do interior (semiárido) nordestino, marcadas por municípios de baixo contingente populacional.

Enquanto a migração de retorno inter-regional no Nordeste, tendo como origem o Estado de São Paulo, apresentou uma elevada proporção de retornados em municípios com até 50 mil habitantes (57,4\% e 56\%), e seguido pelo Distrito Federal (53,1\% e $48,2 \%$ ) e Rio de Janeiro ( $48 \%$ e 47,2\%), os demais Estados apresentaram uma menor proporção de retornados para municípios pequenos (48,9\% e 43,5\%). Esse padrão era esperado, pois, como a proporção de retornados para o próprio município de nascimento era menor nos demais estados, os imigrantes que não voltam para o próprio município de nascimento tenderiam a retornar, por hipótese, para municípios de maior contingente populacional (se considerar o tamanho populacional como proxy para desenvolvimento, infraestrutura de serviços e oportunidades econômicas).

No mesmo sentido, esse argumento justificaria a maior proporção de retornados inter-regionais para municípios com mais de 100 mil habitantes (municípios médios ou grandes) dentre os que retornam para a Unidade da Federação de nascimento, mas não para o próprio município (41,3\% e 42,9\%); em comparação com os retornados ao próprio município de nascimento $(23,7 \%$ e $30 \%)$, nos dois períodos analisados. 


\subsection{Fluxos migratórios inter-regionais de retorno de data fixa, para os municípios do Nordeste}

Como já fora discutido, a migração inter-regional de retorno de data fixa para o próprio município de nascimento representa 54,9\% (191.967) e 61,8\% (177.740) das migrações inter-regionais de retorno de data fixa (nos quinquênios 1995-2000 e 20052010), e, desse total, 62,4\% (119.863) e 54,9\% (97.539) desses retornados têm como destino municípios com até 50 mil habitantes, nos dois períodos em análise. A Figura 1 mostra que grande parte desses fluxos tem como origem o município de São Paulo, sendo que o Estado de São Paulo representa $63,7 \%$ e 54,7\% do total, nos dois quinquênios, e cujo destino é polarizado para todos os Estados do Nordeste. Nos dois períodos analisados, os migrantes retornados do Rio de Janeiro tiveram como destino principal os Estados da Paraíba e do Ceará.

No nível municipal, dentre os principais fluxos migratórios, vale destacar para ambos os quinquênios, um grupo de municípios nas regiões norte e nordeste da Bahia, além de municípios vizinhos na porção Oeste do Estado do Ceará e Norte do Piauí, sendo os principais: Guaraciaba do Norte, Ipu, Ipueiras, Pedro II. Nota-se também um conjunto de municípios no agreste nordestino, em especial nos estados de Pernambuco e Paraíba.

Quando se considera a migração inter-regional de retorno de data fixa para a Unidade da Federação de nascimento (mas não para o próprio município), pode-se verificar, do período 1995-2000 para 2005-2010, uma redução de 45,1\% para 38,2\% em relação ao total de migrações inter-regionais. Nos dois quinquênios, a proporção desses retornados (para a UF, mas não para o município de nascimento) em municípios com até 50 mil habitantes se manteve estável, 43,4\% (68.526) e 42,5\% (46.693), mas num nível bem inferior à proporção de retornados para o próprio município de nascimento (ver Tabela 2, em anexo).

No nível municipal, no quinquênio 1995-2000, destacam-se municípios de destino no interior da Bahia, especialmente na região sul do Estado, como é o caso dos municípios de Poções e Serra do Ramalho. Já no quinquênio 2005-2010, não se observa grandes concentrações espaciais nos fluxos migratórios, destacando apenas o município de Lajedo (PE) [Figura 2]. 
Figura 1 - Fluxos migratórios inter-regionais, de retorno de data fixa (para o próprio município de nascimento), para os municípios do Nordeste entre 0 e 50 mil habitantes: quinquênios 1995-2000 (esquerda) e 2005-2010 (direita)
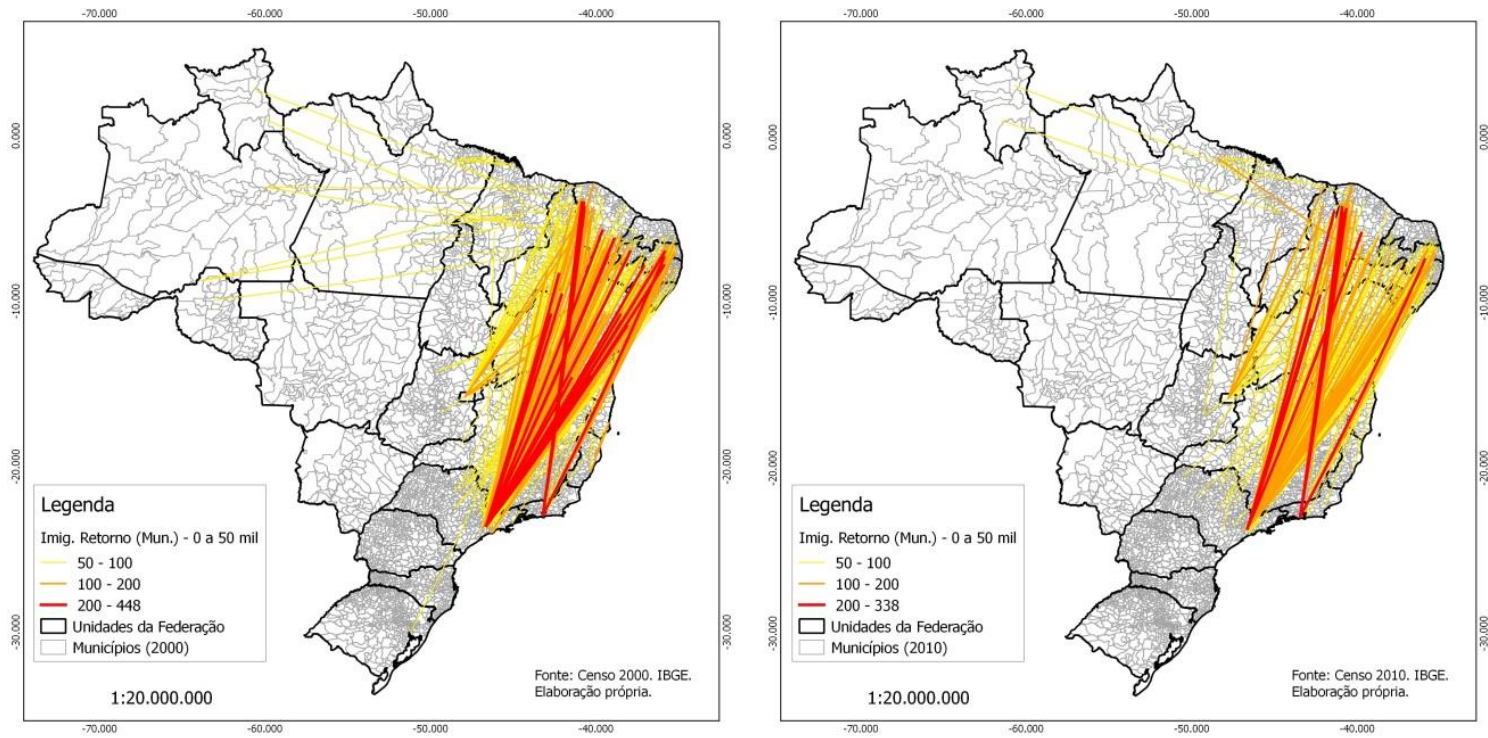

Fonte: IBGE, Censos Demográficos 2000 e 2010. Elaboração própria.

Figura 2 - Fluxos migratórios inter-regionais, de retorno de data fixa (para a UF de nascimento), para os municípios do Nordeste entre 0 e 50 mil habitantes:

quinquênios 1995-2000 (esquerda) e 2005-2010 (direita)
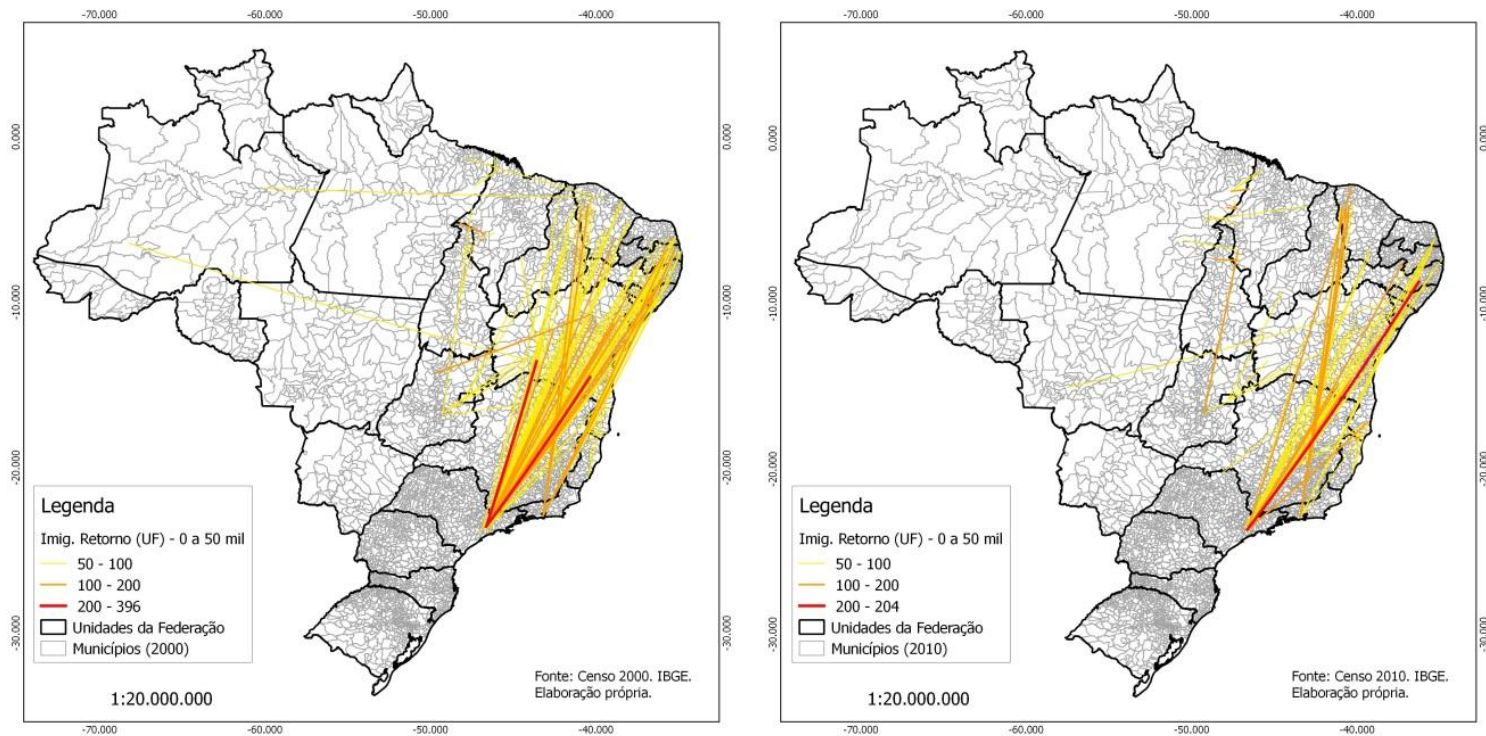

Fonte: IBGE, Censos Demográficos 2000 e 2010. Elaboração própria.

As migrações inter-regionais de retorno de data fixa, para municípios entre $50 \mathrm{e}$ 100 mil habitantes correspondem a $14,5 \%$ e $14,9 \%$ do total das migrações interregionais para o Nordeste, nos dois quinquênios. A Figura 3 apresenta os fluxos migratórios para estes municípios de destino (50 a 100 mil habitantes), para os retornados ao próprio município de nascimento, nos quinquênios 1995-2000 e 2005- 
2010. São Paulo novamente é origem de grande parte do retorno inter-regional (para o próprio município de nascimento) no Nordeste (65\%), sendo que 70,4\% e 63,6\% desses migrantes têm como destino os Estados do Ceará (principalmente na porção oeste do Estado), Pernambuco e a Bahia (principalmente na porção nordeste), nos dois quinquênios.

Ainda na Figura 3, observa-se um importante fluxo de retorno em 1995-2000 para o município de Iguatú, localizado ao sul do Ceará, e tendo como origem o município de São Paulo. Ademais, destacam-se nos dois quinquênios, fluxos de retorno para o próprio município de nascimento (entre 50 e 100 mil) para as regiões do sul do Ceará, nordeste da Bahia, e, de maneira mais geral, numa grande quantidade de municípios interioranos, que remetem à origem do processo emigratório da Região Nordeste no passado, juntamente com os mapas dos municípios de pequeno contingente populacional, das Figuras 1 e 2.

A Figura 4 apresenta os fluxos migratórios de retorno inter-regional (para a UF de nascimento) no Nordeste, e para municípios entre 50 e 100 mil habitantes, nos quinquênios 1995-2000 e 2005-2010. Somente 15,3\% (em 1995-2000) e 14,6\% (em 2005-2010) dos retornados inter-regionais e não naturais do Nordeste, tem como destino municípios dessa hierarquia populacional.

A redução no volume das migrações inter-regionais, no período em análise, modifica visualmente os dois mapas, pois, no segundo período, não se observa fluxos migratórios acima de 200 pessoas, o que resulta numa aparente distribuição desconcentrada das migrações de retorno (enquanto São Paulo continua sendo a principal origem). Porém, nos dois quinquênios, o Estado da Bahia foi responsável por, respectivamente, $30,2 \%$ e $27,8 \%$ das migrações de retorno inter-regional para o Nordeste, em municípios entre 50 e 100 mil habitantes, e cujos retornados são não naturais. No entanto, esse retorno "concentrado" novamente na Bahia não surpreende, pois, como já fora comentado, este Estado apresenta um maior volume de emigrantes nas últimas décadas, em comparação com as demais UF's do Nordeste. Ademais, é importante destacar, nos dois quinquênios, a existência de alguns municípios pertencentes a RM's (em especial de Salvador e Fortaleza), o que é indício da busca por oportunidades de trabalho, para aqueles que não retornam ao próprio município de nascimento. 
Figura 3 - Fluxos migratórios inter-regionais, de retorno de data fixa (para o próprio município de nascimento), para os municípios do Nordeste entre 50 e 100 mil habitantes: quinquênios 1995-2000 (esquerda) e 2005-2010 (direita)
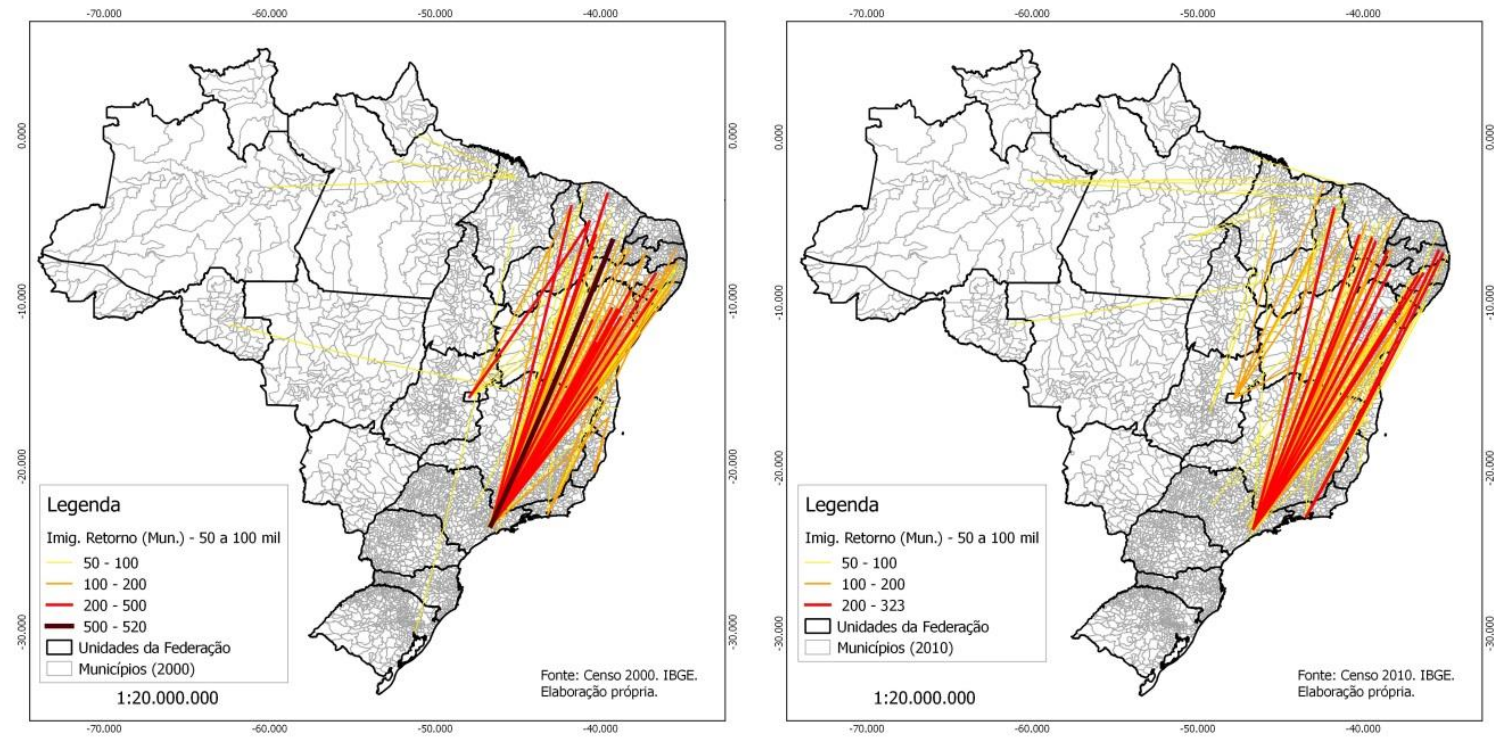

Fonte: IBGE, Censos Demográficos 2000 e 2010. Elaboração própria.

Figura 4 - Fluxos migratórios inter-regionais, de retorno de data fixa (para a UF de nascimento), para os municípios do Nordeste entre 50 e 100 mil habitantes: quinquênios 1995-2000 (esquerda) e 2005-2010 (direita)
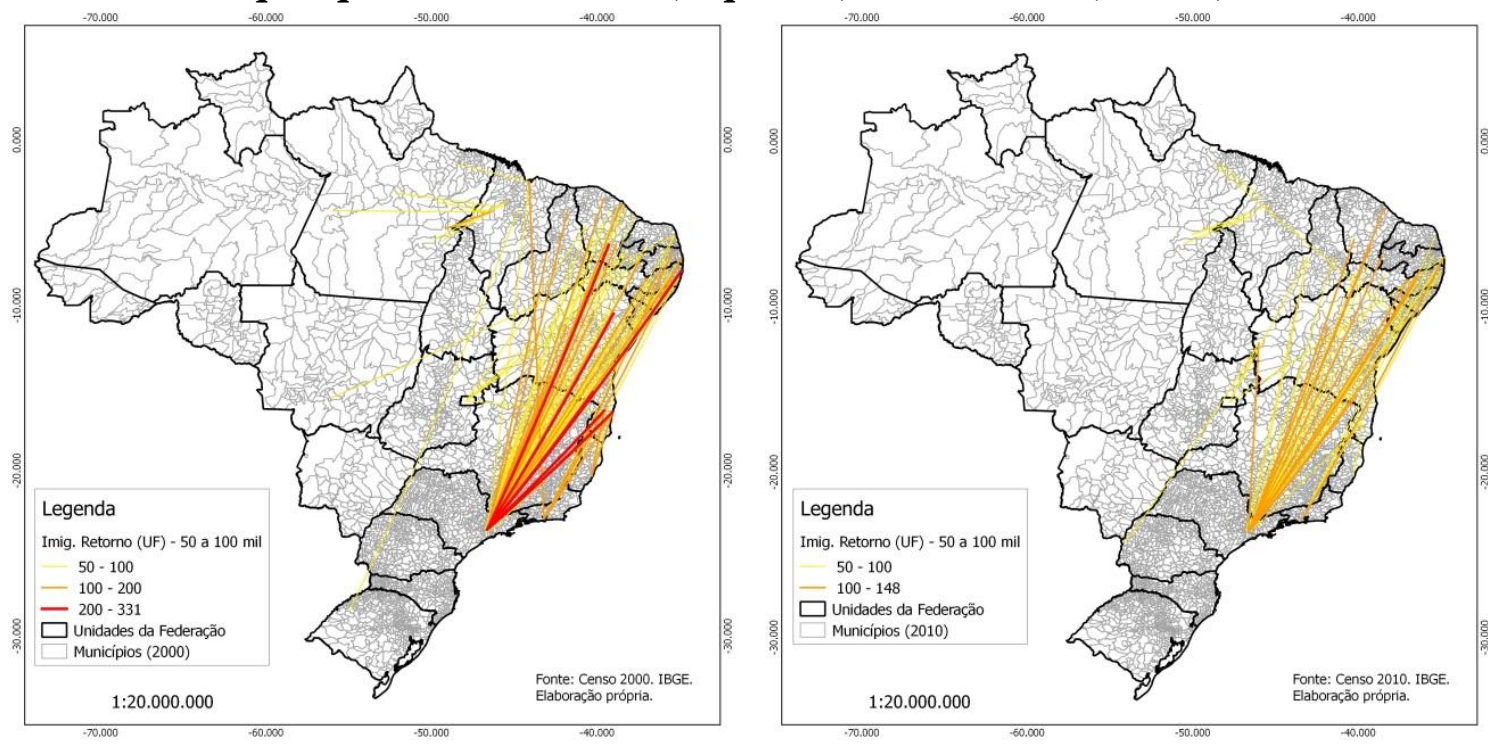

Fonte: IBGE, Censos Demográficos 2000 e 2010. Elaboração própria.

As Figuras 5 e 6 apresentam os fluxos migratórios de retorno inter-regional no Nordeste, para o próprio município de nascimento (Figura 5) e para a UF de nascimento (Figura 6), para municípios de destino com tamanho populacional entre 100 mil e 500 mil habitantes, nos quinquênios 1995-2000 e 2005-2010. Os fluxos migratórios com destino para os municípios entre 100 e 500 mil habitantes representam 15,2\% e 16,6\% 
da migração de retorno inter-regional para a Região Nordeste, dos quais 59,6\% e 49,9\% desse montante são retornados para a UF de nascimento, mas não para o próprio município (respectivamente aos dois quinquênios). Enquanto os municípios entre 100 e 500 mil habitantes representavam $11,2 \%$ e $13,5 \%$ do volume total de retornados naturais do município, o peso dos municípios entre 100 e 500 mil habitantes aumenta para $20,1 \%$ e $21,7 \%$ no volume de retornados não naturais do município (porém à UF). Assim, se confirma a hipótese de que municípios com maior contingente populacional apresentam um maior poder de atração de migrantes retornados não naturais.

Os mapas das Figuras 5 e 6 mostram um padrão semelhante, justamente pelo pequeno número de municípios com este contingente populacional (apenas 47 dos 1.794 municípios nordestinos), no qual se destacam a prevalência de São Paulo como origem, e tendo a Bahia como principal destino. Vitória da Conquista, por exemplo, foi o principal destino em volume, nos dois períodos; além de outras regiões do Estado, como Itabuna e Ilhéus, que apresentaram importantes fluxos de retorno e que curiosamente são regiões marcadas pela estagnação econômica, nos últimos anos.

No caso dos fluxos para municípios do Estado de nascimento (mas não para o município), entre 100 e 500 mil habitantes (Figura 6), a grande diferença foi o retorno para municípios de regiões metropolitanas, como Paulista (PE), Parnamirim (RN), Caucaia e Maracanaú (CE), o que novamente é um indício da busca por oportunidades de trabalho, para aqueles que não retornam ao próprio município de nascimento. Contudo, os fluxos de maior magnitude ocorreram em direção a cidades médias distantes das capitais, como é o caso de Juazeiro do Norte (CE) e Feira de Santana (BA) no quinquênio 1995-2000, e Vitória da Conquista (BA) nos dois quinquênios.

Ademais, nos dois períodos se observa um conjunto de municípios do agreste nordestino, nos estados de Alagoas (ex. Arapiraca), Pernambuco (ex. Caruarú e Garanhuns) e Paraíba (Campina Grande), que formam um eixo bem definido de retorno, tendo como origem os municípios do Rio de Janeiro e São Paulo, principalmente. Chama à atenção um conjunto de fluxos de elevada magnitude (acima de 200 pessoas) que suscita à existência de redes migratórias bem definidas em Barreiras, no oeste da Bahia, e Parnaíba, no Piauí, e tendo origem o Distrito Federal. 
Figura 5 - Fluxos migratórios inter-regionais, de retorno de data fixa (para o próprio município de nascimento), para os municípios do Nordeste entre 100 e 500 mil habitantes: quinquênios 1995-2000 (esquerda) e 2005-2010 (direita)
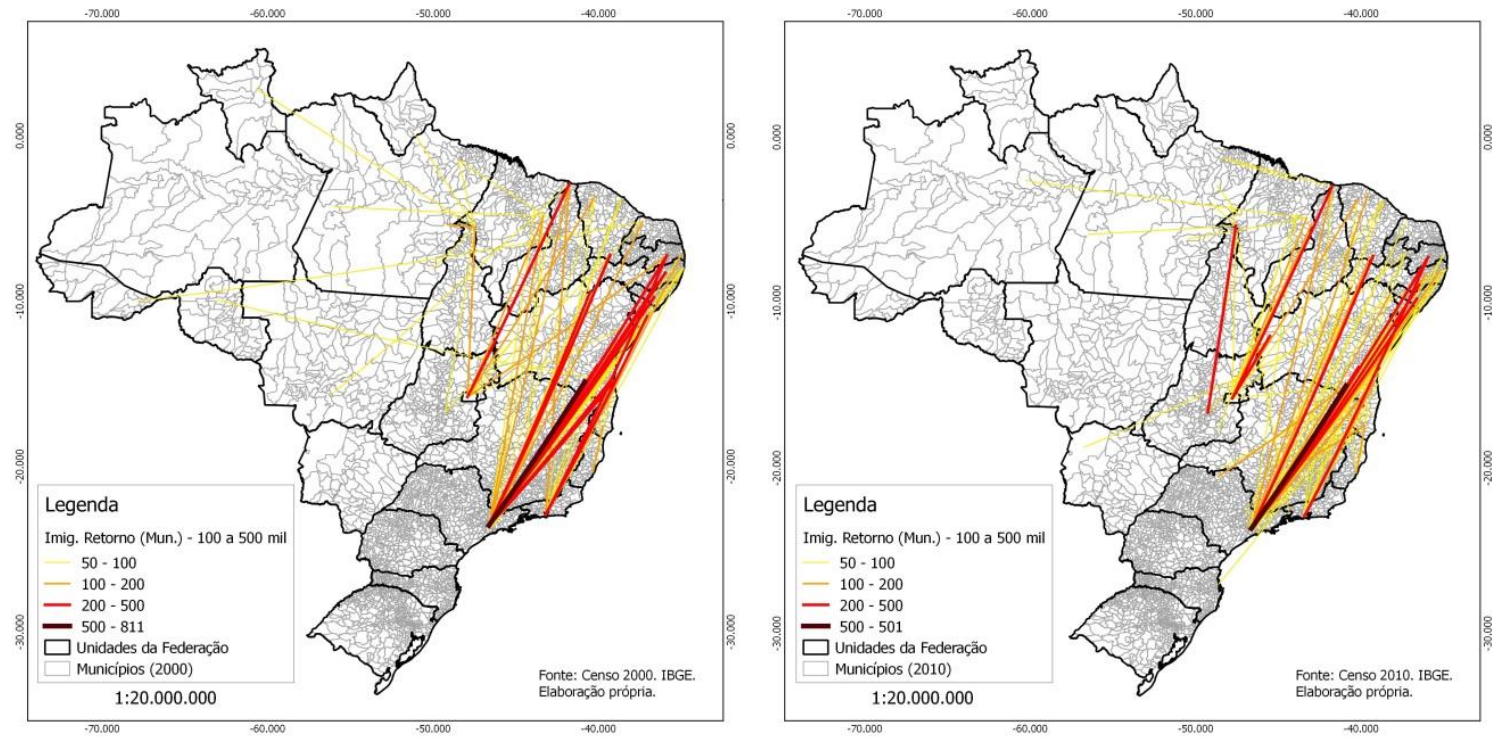

Fonte: IBGE, Censos Demográficos 2000 e 2010. Elaboração própria.

Figura 6 - Fluxos migratórios inter-regionais, de retorno de data fixa (para a UF de nascimento), para os municípios do Nordeste entre 100 e 500 mil habitantes: quinquênios 1995-2000 (esquerda) e 2005-2010 (direita)
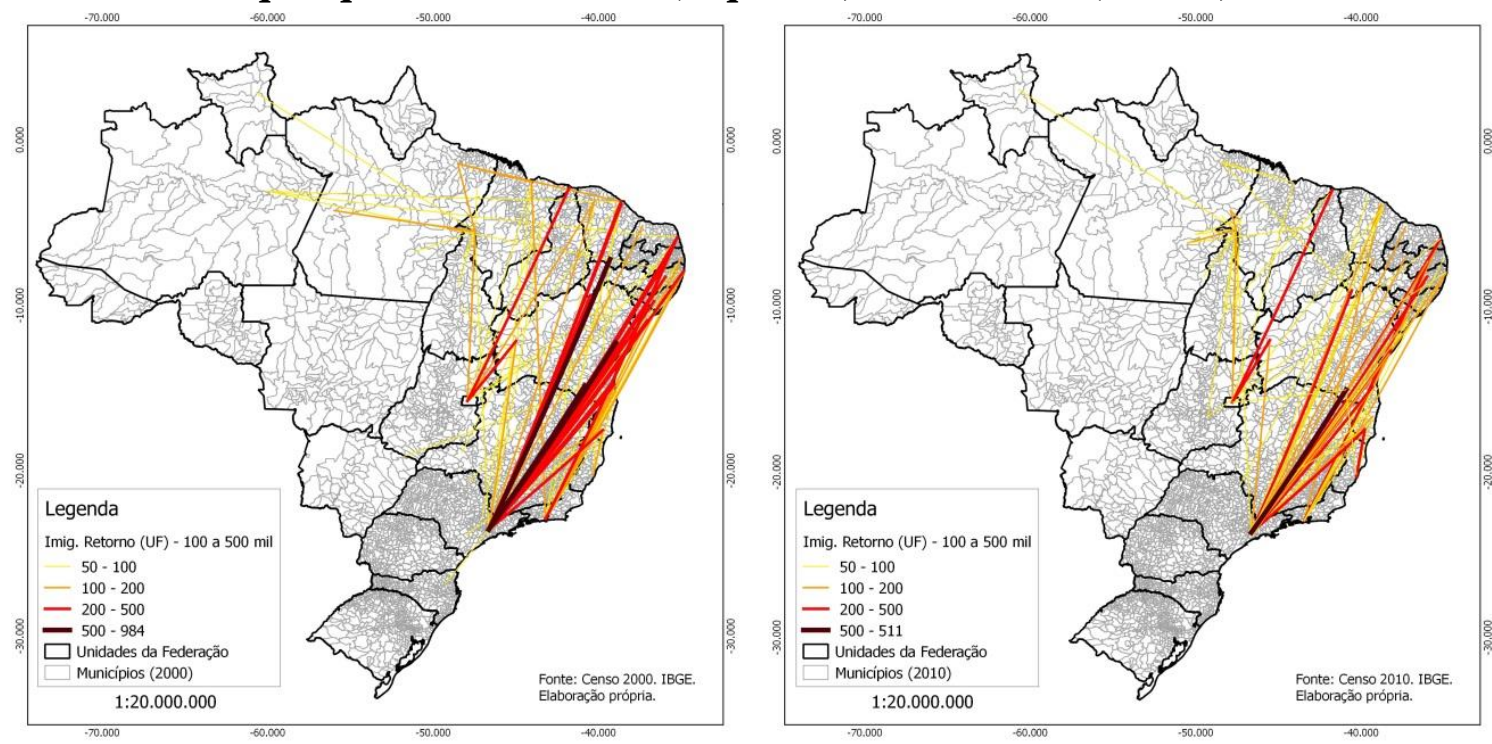

Fonte: IBGE, Censos Demográficos 2000 e 2010. Elaboração própria.

As Figuras 7 e 8 apresentam os fluxos migratórios de retorno inter-regional no Nordeste, para o próprio município de nascimento (Figura 7), para a UF de nascimento (Figura 8), e para municípios de destino com tamanho populacional entre 500 mil e 1 milhão de habitantes, nos quinquênios 1995-2000 e 2005-2010. O padrão é similar nos dois períodos e segundo o status de naturalidade no retorno. Enquanto o município de 
São Paulo é conectado com fluxos migratórios para todos os municípios nos dois períodos, o município do Rio de Janeiro apresenta fluxos importantes com municípios da porção leste da Região Nordeste, com destaque para João Pessoa (PB) e Natal (RN). Por sua vez, o Distrito Federal é origem de importantes fluxos de retorno com destino na porção oeste do Nordeste, mais especificamente com Teresina (PI) e São Luís (MA), este último apenas no quinquênio 1995-2000.

São Paulo e Rio de Janeiro (através de suas regiões metropolitanas) correspondem a 42,4\% do total da migração de retorno inter-regional para os municípios entre 500 mil e 1 milhão de habitantes, no quinquênio 1995-2000; proporção que aumenta para 48,5\% no quinquênio 2005-2010. Essas migrações, relacionadas às cidades litorâneas da porção leste da Região Nordeste (como fora comentado) estão provavelmente vinculadas a oportunidades econômicas, dado que, nos dois quinquênios, os poucos municípios entre 500 mil e 1 milhão de habitantes representavam pouco mais de $11 \%$ do total de retornados inter-regionais, naturais da UF e não-naturais do município (contra 5,9\% em 2000 e 7,9\% em 2010, de retornados naturais do município).

Figura 7 - Fluxos migratórios inter-regionais, de retorno de data fixa (para o próprio município de nascimento), para os municípios do Nordeste entre 500 mil e 1 milhão de habitantes: quinquênios 1995-2000 (esquerda) e 2005-2010 (direita)
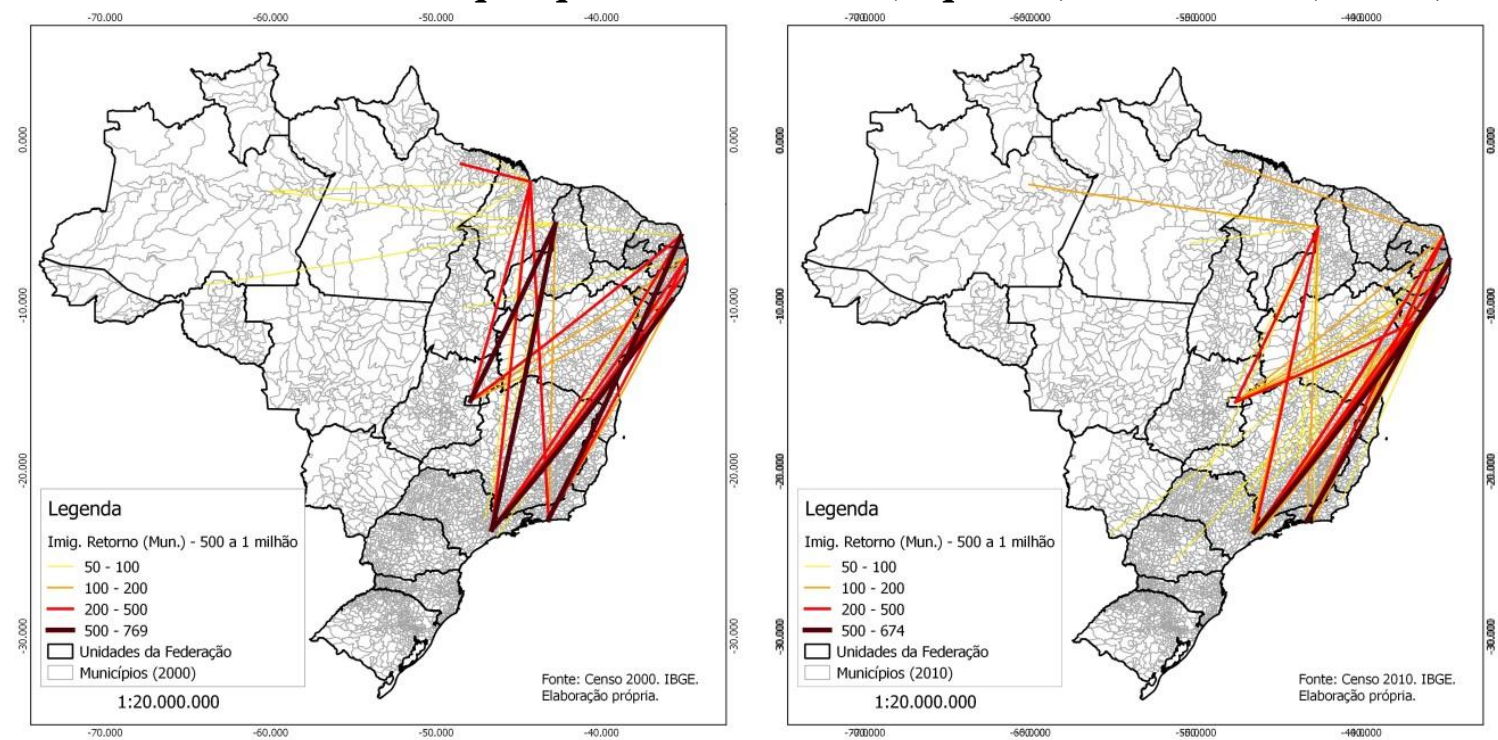

Fonte: IBGE, Censos Demográficos 2000 e 2010. Elaboração própria. 
Figura 8 - Fluxos migratórios inter-regionais, de retorno de data fixa (para a UF de nascimento), para os municípios do Nordeste entre 500 mil e 1 milhão de habitantes: quinquênios 1995-2000 (esquerda) e 2005-2010 (direita)
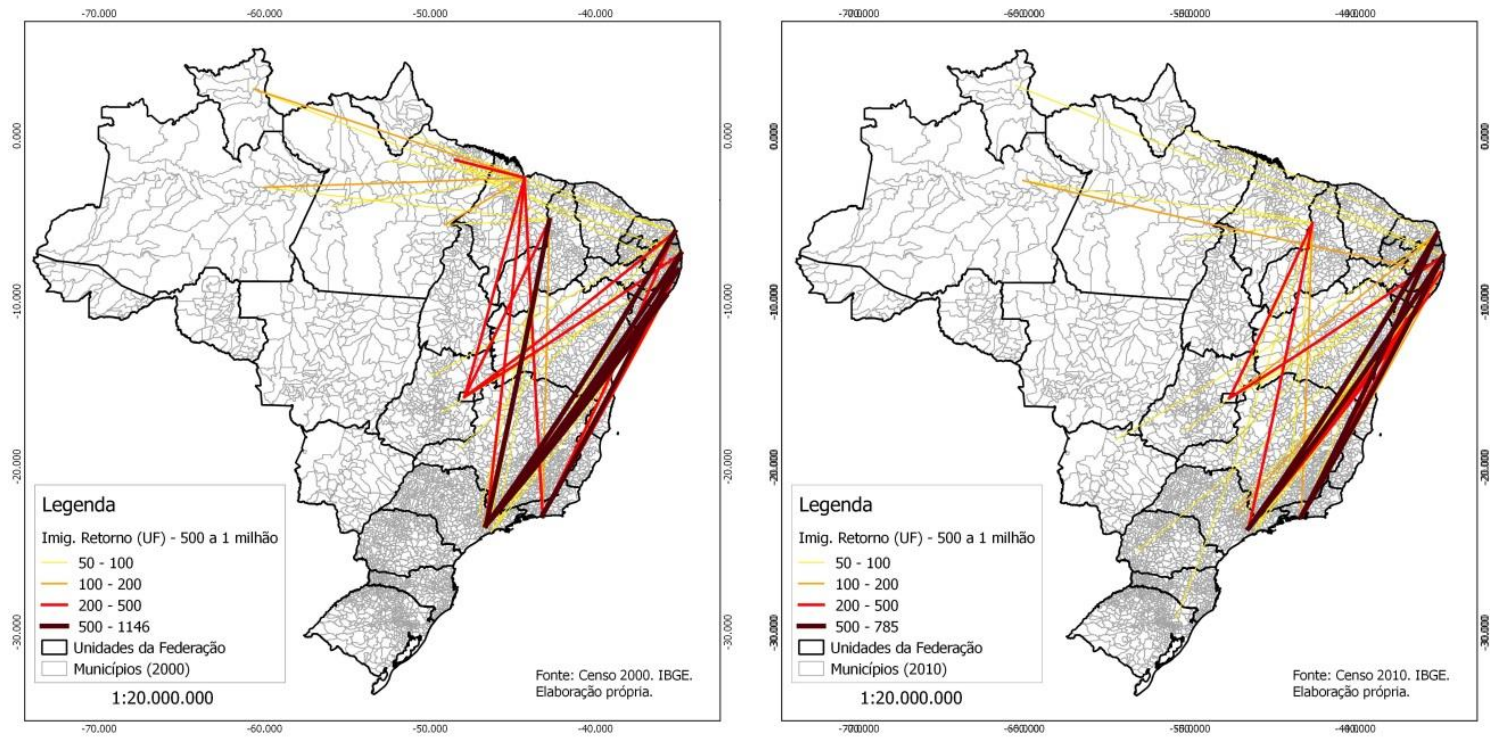

Fonte: IBGE, Censos Demográficos 2000 e 2010. Elaboração própria.

As Figuras 9 e 10 apresentam os fluxos migratórios de retorno inter-regional no Nordeste, para o próprio município de nascimento (Figura 9) e para a UF de nascimento (Figura 10), e para municípios de destino com população acima de 1 milhão de habitantes, nos quinquênios 1995-2000 e 2005-2010. Apenas três municípios apresentaram este tamanho populacional em 2000, e quatro em 2010 (com a inclusão de São Luís, Maranhão): Salvador (31,1\% e 26,7\%), Recife (22\% e 20,7\%), Fortaleza (46,9\% e 33,5\%) e São Luís $(19,1 \%)$, cujas proporções representam o volume total de retornados inter-regionais para municípios acima de 1 milhão de habitantes, nos dois quinquênios. A maioria destes retornados são naturais da UF e não naturais do município no quinquênio 1995-2000 (54,9\%), proporção que se inverte no quinquênio 2005-2010 (40,3\%). Novamente os Estados de São Paulo, Rio de Janeiro (ambos através de suas respectivas capitais) e Distrito Federal foram origens de 71,5\% e 58\%, do total de retornados inter-regionais para municípios com mais de 1 milhão de habitantes, nos dois períodos.

Os fluxos de retorno para o município ou para o Estado (mas não o município) de nascimento apresentam um padrão espacial similar, e para os dois períodos, em parte devido à pequena relação de municípios dessa hierarquia de tamanho populacional. Rio de Janeiro e principalmente São Paulo apresentam forte conexão com todas as capitais, nos dois períodos e para os dois tipos de retorno (para o município e para a UF). O 
Distrito Federal, assim como nas demais hierarquias dos municípios de destino, apresenta fluxos mais importantes com Fortaleza (CE), mas, principalmente, com São Luís do Maranhão.

Figura 9 - Fluxos migratórios inter-regionais, de retorno de data fixa (para o próprio município de nascimento), para os municípios do Nordeste com mais de 1 milhão de habitantes: quinquênios 1995-2000 (esquerda) e 2005-2010 (direita)
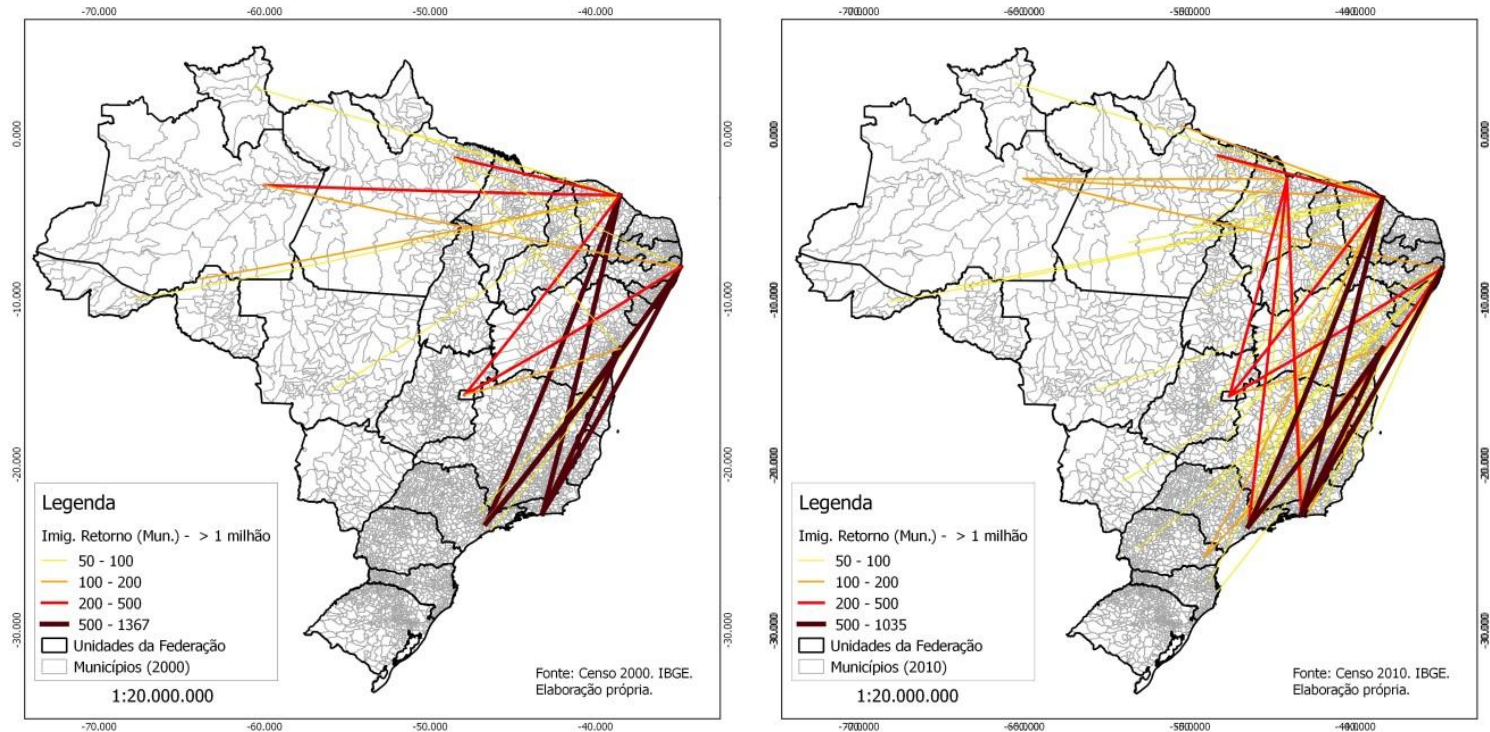

Fonte: IBGE, Censos Demográficos 2000 e 2010. Elaboração própria.

Figura 10 - Fluxos migratórios inter-regionais, de retorno de data fixa (para a UF de nascimento), para os municípios do Nordeste com mais de 1 milhão de habitantes: quinquênios 1995-2000 (esquerda) e 2005-2010 (direita)
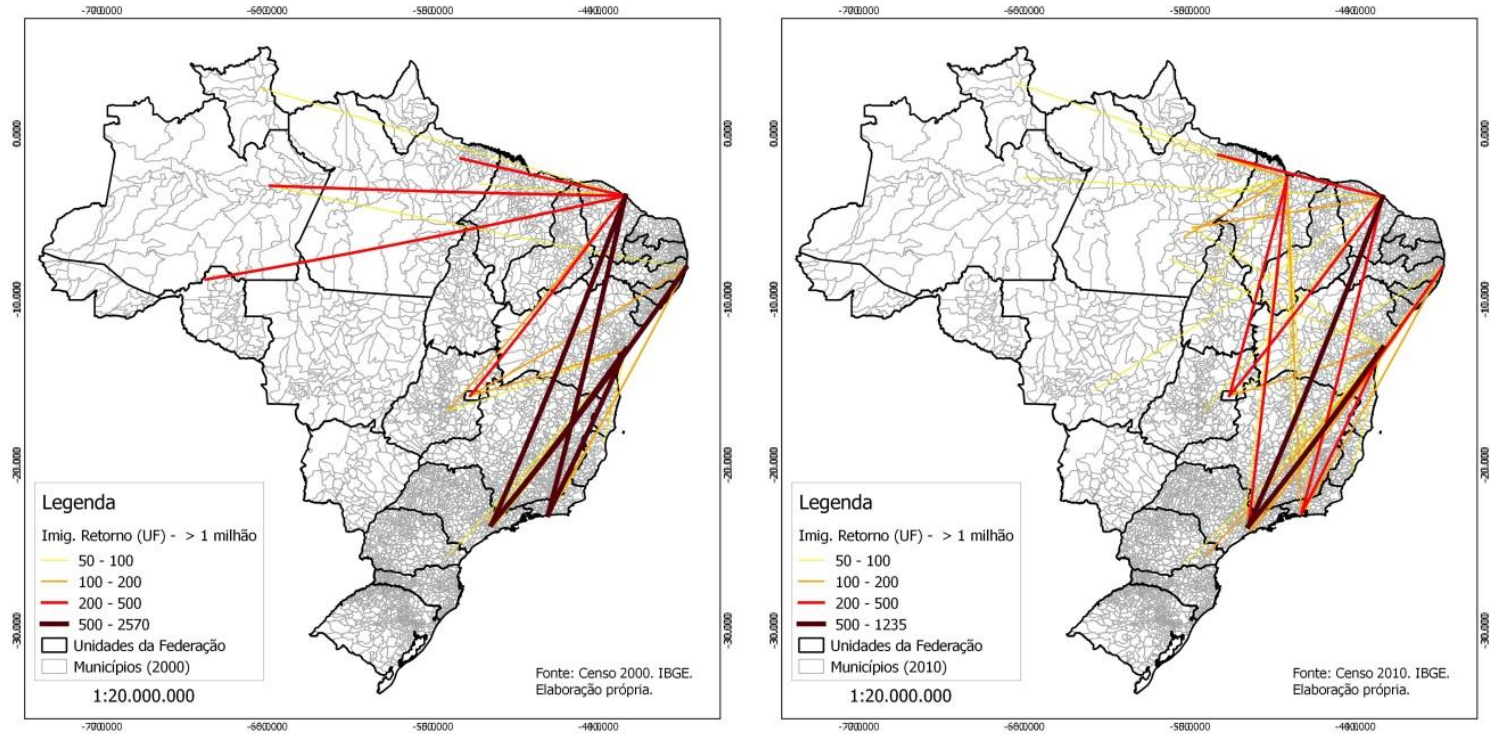

Fonte: IBGE, Censos Demográficos 2000 e 2010. Elaboração própria. 


\section{Considerações Finais}

Historicamente, a migração de retorno ao Nordeste é consequência das tendências históricas de perdas líquidas de população dessa região, que ao longo de décadas atuou como reservatório de mão de obra para regiões economicamente desenvolvidas, em especial para o município de São Paulo. Mais recentemente, em paralelo à redução das perdas populacionais, a Região Nordeste tem apresentado um aumento da migração de retorno, fenômeno este que tem se tornado uma das tendências mais importantes da dinâmica migratória e da redistribuição espacial da população brasileira.

Nesse contexto, este trabalho buscou aprofundar a análise da migração de retorno no Nordeste, a partir de uma perspectiva espacial, com o objetivo de se compreender melhor como os fluxos migratórios de retorno impactam na dinâmica de redistribuição espacial da população no Nordeste. E, para tanto, foi realizado um esforço para a construção dos fluxos migratórios no nível municipal, e segundo hierarquia dos municípios de destino e status de naturalidade do retorno.

Dentre os resultados, foi possível reiterar a importância do município de São Paulo como principal origem da migração de retorno para o Nordeste, e seguido pelo município do Rio de Janeiro e Distrito Federal. Essas origens, por sua vez, apresentam seletividades nos fluxos migratórios, que podem estar associados com redes de migração, como é o caso do retorno (importante em volume) com origem em São Paulo e destino no interior da Bahia e, de forma mais geral, no semiárido nordestino; os fluxos de retorno com origem no Rio de Janeiro e tendo como destino o litoral, especialmente da Paraíba e Pernambuco; e importantes fluxos de retornados entre Distrito Federal e municípios da porção oeste da Região Nordeste, em especial os Estados do Maranhão e Piauí.

Em relação à naturalidade, observa-se a prevalência da migração de retorno inter-regional para o próprio município de nascimento, sendo que a maioria dos retornados tem como destino municípios pequenos, com até 50 mil habitantes, o que reflete a importância das perdas populacionais no passado, de áreas estagnadas do interior (semiárido) nordestino, marcadas por municípios de baixo contingente populacional. Porém, foi possível observar que a proporção de migrantes que retornam para outro município do Estado de nascimento é também significativa, e que, neste caso, a migração de retorno ocorre, preferencialmente para municípios de médio e/ou de 
grande porte populacional (considerando o tamanho populacional como uma proxy para a busca de oportunidades econômicas).

Um dos desafios recentes na agenda internacional dos estudos sobre mobilidade é a necessidade de associação dos fenômenos migratórios com o desenvolvimento, bem como os fatores causais subjacentes às migrações (DE HAAS, 2010). Nesse sentido, algumas questões podem ser levantadas, como possíveis relações entre o retorno ao próprio município de nascimento e a melhoria nas condições de vida local, como, por exemplo, o aumento dos programas de transferência de renda no Nordeste, especialmente nos municípios mais pobres, e que foram, por sua vez, a origem de grande parte dos emigrantes no passado (SIQUEIRA, MAGALHÃES E SILVEIRA NETO, 2008).

Por sua vez, o importante volume de retornados não naturais (para o Estado de nascimento, mas não para o município de origem), pode estar associado a fatores econômicos na origem, tais como a expansão do polo petroquímico de Camaçari, o polo têxtil de Fortaleza, o complexo mineiro-metalúrgico de Carajás, o polo agroindustrial de Petrolina/Juazeiro, entre outros (ARAÚJO, 1995). Como afirma Siqueira, Magalhães e Silveira (2008), todos esses fenômenos na origem, somados ao desemprego, a falta de oferta na moradia, a violência e a dificuldade no acesso a serviços públicos, no destino, contribuem em alguma medida para a redução da emigração e para o aumento da imigração de retorno, no Nordeste.

Portanto, a partir da análise realizada sobre o padrão espacial dos fluxos migratórios de retorno ao Nordeste, uma agenda para estudos futuros trata-se da investigação do perfil dos retornados e, consequentemente, os fatores causais associados a este fenômeno. 


\section{Referências Bibliográficas}

ARAUJO, T.B. Nordeste, Nordestes, que Nordeste. In: Affonso R. de B, Silva, P.L.B. (org). Desigualdade e Desenvolvimento. São Paulo: Fundap, Unesp (Série Federalismo no Brasil).

BAENINGER, R. Novos Espaços da Migração no Brasil: Anos 80 e 90...In: XII ENCONTRO NACIONAL DE ESTUDOS POPULACIONAIS, 2000, Caxambu. Anais... Belo Horizonte: ABEP, 2000.

BAPTISTA, E. A., CAMPOS, J., RIGOTTI, J. I. R. Migração de retorno no Brasil nos quinquênios 1986/1991, 1995/2000 e 2005/2010. In: XVIII Encontro Nacional de Estudos Populacionais. ABEP, Águas de Lindóia, 2012.

BRITO, F., RIGOTTI, J. I. R., CAMPOS, J. A mobilidade interestadual da população no Brasil no início do século XXI: mudança no padrão migratório? In: Textos para Discussão (série online de publicações do CEDEPLAR), CEDEPLAR/UFMG, Belo Horizonte, 2012.

CUNHA, J. M. P.; BAENINGER, R. A migração nos estados brasileiros no período recente: principais tendências e mudanças. Bahia Análise \& Dados, Salvador BA/SEI, v.10, n.4, p.79-106, mar. 2001.

DE HAAS, H.. Migration transitions: a theoretical and empirical inquiry into the developmental drivers of international migration. WorkingPapersSeries, 24, 2010.

FAZITO, D. Dois aspectos fundamentais do "retorno": símbolos e topologias dos processos de migração e sua circularidade. Belo Horizonte: CEDEPLAR/UFMG, 2005, $16 \mathrm{p}$.

GARCIA, R., MIRANDA-RIBEIRO, A. Movimentos migratórios em Minas Gerais: efeitos diretos e indiretos da migração de retorno, 1970/1980, 1981/1991 e 1990/2000. Revista Brasileira de Estudos Populacionais, 22(1), p. 159-175, 2005.

INSTITUTO BRASILEIRO DE GEOGRAFIA E ESTATÍSTICA - IBGE. Microdados do Censo Demográfico 2000. Rio de Janeiro, 2000.

INSTITUTO BRASILEIRO DE GEOGRAFIA E ESTATÍSTICA - IBGE. Microdados do Censo Demográfico 2010. Rio de Janeiro, 2010.

RIBEIRO, J. T. L. Estimativa da migração de retorno e de alguns de seus efeitos demográficos indiretos no nordeste brasileiro, 1970/1980 e 1981/1991. 1997, 206 p. Tese (Doutorado em Demografia) - Centro de Desenvolvimento e Planejamento Regional, Universidade Federal de Minas Gerais, Belo Horizonte. 
SIQUEIRA, L.B.O; MAGALHÃES, A.M e SILVEIRA NETO, R. M. Uma análise de migração de Retorno no Brasil: Perfil do migrante de Retorno, a Partir do Censo de 2000. In: XI Encontro Regional de Economia, 2006, Fortaleza. Anais...2006.

\section{Anexo}

Tabela 1 - Nordeste: Migração de Retorno, por Município eUnidade da Federação de nascimento, por principais Estados de origem e Hierarquia de Cidades no

\begin{tabular}{|c|c|c|c|c|c|c|c|c|c|c|c|c|}
\hline \multirow{2}{*}{$\begin{array}{c}\text { Principais } \\
\text { UF's de } \\
\text { Origem } \\
\end{array}$} & \multirow{2}{*}{$\begin{array}{l}\text { Migração de } \\
\text { retorno (tipo) }\end{array}$} & \multirow{2}{*}{$\begin{array}{c}\text { Hierarquia dos } \\
\text { municípios de } \\
\text { destino (hab.) }\end{array}$} & \multicolumn{9}{|c|}{ Unidades da Federação } & \multirow{2}{*}{ Total } \\
\hline & & & Maranhão & Piauí & Ceará & Rio Grande do Norte & Paraíba & Pernambuco & Alagoas & Sergipe & Bahia & \\
\hline \multirow{13}{*}{$\begin{array}{c}\text { Total } \\
\text { (Brasil) }\end{array}$} & \multirow{6}{*}{$\begin{array}{l}\text { Retorno para o } \\
\text { município de } \\
\text { nascimento }\end{array}$} & Total & 14.385 & 18.087 & 36.956 & 9.283 & 21.489 & 27.822 & 8.401 & 4.308 & 51.236 & 191.967 \\
\hline & & Até 50 mil & 7.226 & 12.836 & 23.204 & 5.662 & 15.997 & 14.981 & 4.679 & 2.763 & 32.515 & 119.863 \\
\hline & & 50 a 100 mil & 1.969 & 1.647 & 5.741 & 500 & 2.017 & 5.221 & 1.021 & 736 & 7.811 & 26.663 \\
\hline & & 100 a 500 mil & 3.154 & 907 & 2.559 & 622 & 1.828 & 3.321 & 875 & 809 & 7.463 & 21.538 \\
\hline & & 500 mil a 1 milhão & 2.036 & 2.697 & 0 & 2.499 & 1.647 & 659 & 1.826 & 0 & 0 & 11.364 \\
\hline & & 1 milhão e mais & 0 & 0 & 5.452 & 0 & 0 & 3.640 & 0 & 0 & 3.447 & 12.539 \\
\hline & \multirow{6}{*}{$\begin{array}{l}\text { Retorno para a } \\
\text { Unidade da } \\
\text { Federação de } \\
\text { nascimento }\end{array}$} & Total & 21.636 & 10.275 & 25.093 & 9.790 & 14.118 & 21.990 & 7.041 & 3.202 & 44.784 & 157.929 \\
\hline & & Até 50 mil & 9.668 & 5.138 & 9.237 & 3.888 & 7.278 & 7.364 & 3.387 & 1.510 & 21.056 & 68.526 \\
\hline & & 50 a 100 mil & 4.330 & 915 & 3.797 & 894 & 1.673 & 3.997 & 677 & 568 & 7.300 & 24.151 \\
\hline & & 100 a 500 mil & 4.181 & 513 & 4.479 & 1.675 & 1.881 & 5.885 & 770 & 1.124 & 11.246 & 31.754 \\
\hline & & 500 mil a 1 milhão & 3.457 & 3.709 & 0 & 3.333 & 3.286 & 2.267 & 2.207 & 0 & 0 & 18.259 \\
\hline & & 1 milhão e mais & 0 & 0 & 7.580 & 0 & 0 & 2.477 & 0 & 0 & 5.182 & 15.239 \\
\hline & TOTAL & & 36.021 & 28.362 & 62.049 & 19.073 & 35.607 & 49.812 & 15.442 & 7.510 & 96.020 & 349.896 \\
\hline \multirow{13}{*}{ São Paulo } & & Total & 2.377 & 10.479 & 19.361 & 4.553 & 11.721 & 20.489 & 6.634 & 2.994 & 36.732 & 115.340 \\
\hline & & Até 50 mil & 1.149 & 8.098 & 12.027 & 3.134 & 9.054 & 12.048 & 3.884 & 2.172 & 24.839 & 76.405 \\
\hline & município de & 50 a 100 mil & 162 & 1.204 & 3.685 & 248 & 1.266 & 3.766 & 825 & 534 & 5.646 & 17.336 \\
\hline & muscimento & 100 a 500 mil & 626 & 179 & 1.610 & 311 & 884 & 2.341 & 658 & 288 & 4.840 & 11.737 \\
\hline & & 500 mil a 1 milhão & 440 & 998 & 0 & 860 & 517 & 497 & 1.267 & 0 & 0 & 4.579 \\
\hline & & 1 milhão e mais & 0 & 0 & 2.039 & 0 & 0 & 1.837 & 0 & 0 & 1.407 & 5.283 \\
\hline & & Total & 2.575 & 5.686 & 12.714 & 4.771 & 6.443 & 15.002 & 5.151 & 2.103 & 27.458 & 81.903 \\
\hline & Retorno para a & Até 50 mil & 978 & 3.047 & 4.413 & 2.004 & 3.444 & 5.716 & 2.446 & 1.118 & 13.657 & 36.823 \\
\hline & Unidade da & 50 a 100 mil & 439 & 608 & 2.353 & 420 & 855 & 2.850 & 488 & 388 & 4.292 & 12.693 \\
\hline & Federação de & 100 a $500 \mathrm{mil}$ & 621 & 97 & 2.643 & 952 & 830 & 3.707 & 646 & 597 & 6.929 & 17.022 \\
\hline & nascimento & 500 mil a 1 milhão & 537 & 1.934 & 0 & 1.395 & 1.314 & 1.304 & 1.571 & 0 & 0 & 8.055 \\
\hline & & 1 milhão e mais & 0 & 0 & 3.305 & 0 & 0 & 1.425 & 0 & 0 & 2.580 & 7.310 \\
\hline & TOTAL & & 4.952 & 16.165 & 32.075 & 9.324 & 18.164 & 35.491 & 11.785 & 5.097 & 64.190 & 197.243 \\
\hline & & Total & 1.004 & 708 & 6.326 & 1.777 & 5.807 & 2.708 & 564 & 559 & 3.318 & 22.771 \\
\hline & & Até 50 mil & 376 & 297 & 4.992 & 715 & 4.261 & 883 & 223 & 163 & 1.132 & 13.042 \\
\hline & $\begin{array}{l}\text { Retorno para o } \\
\text { município de }\end{array}$ & 50 a 100 mil & 22 & 119 & 375 & 133 & 446 & 536 & 61 & 99 & 295 & 2.086 \\
\hline & $\begin{array}{l}\text { municipio de } \\
\text { nascimento }\end{array}$ & 100 a $500 \mathrm{mil}$ & 170 & 119 & 175 & 49 & 540 & 260 & 40 & 297 & 686 & 2.336 \\
\hline & & 500 mil a 1 milhão & 436 & 173 & 0 & 880 & 560 & 64 & 240 & 0 & 0 & 2.353 \\
\hline & & 1 milhão e mais & 0 & 0 & 784 & 0 & 0 & 965 & 0 & 0 & 1.205 & 2.954 \\
\hline Janeiro & & Total & 1.274 & 442 & 3.637 & 1.951 & 4.722 & 2.352 & 528 & 527 & 3.014 & 18.447 \\
\hline & Retorno para a & Até 50 mil & 285 & 215 & 1.850 & 609 & 2.355 & 463 & 214 & 83 & 666 & 6.740 \\
\hline & Unidade da & 50 a 100 mil & 276 & 8 & 253 & 187 & 501 & 396 & 57 & 62 & 432 & 2.172 \\
\hline & Federação de & 100 a $500 \mathrm{mil}$ & 188 & 24 & 338 & 338 & 717 & 753 & 44 & 382 & 801 & 3.585 \\
\hline & nascimento & 500 mil a 1 milhão & 525 & 195 & 0 & 817 & 1.149 & 365 & 213 & 0 & 0 & 3.264 \\
\hline & & 1 milhão e mais & 0 & 0 & 1.196 & 0 & 0 & 375 & 0 & 0 & 1.115 & 2.686 \\
\hline & TOTAL & & 2.278 & 1.150 & 9.963 & 3.728 & 10.529 & 5.060 & 1.092 & 1.086 & 6.332 & 41.218 \\
\hline & & Total & 1.270 & 2.994 & 2.776 & 687 & 1.433 & 685 & 209 & 114 & 2.080 & 12.248 \\
\hline & & Até 50 mil & 609 & 1.854 & 1.633 & 354 & 1.005 & 264 & 54 & 44 & 1.539 & 7.356 \\
\hline & $\begin{array}{l}\text { Ketorno para o } \\
\text { municínio de }\end{array}$ & 50 a 100 mil & 97 & 210 & 454 & 9 & 109 & 119 & 27 & 0 & 148 & 1.173 \\
\hline & $\begin{array}{l}\text { municipio de } \\
\text { nascimento }\end{array}$ & 100 a $500 \mathrm{mil}$ & 348 & 247 & 207 & 80 & 158 & 66 & 17 & 70 & 211 & 1.404 \\
\hline & & 500 mil a 1 milhão & 216 & 683 & 0 & 244 & 161 & 16 & 111 & 0 & 0 & 1.431 \\
\hline & & 1 milhão e mais & 0 & 0 & 482 & 0 & 0 & 220 & 0 & 0 & 182 & 884 \\
\hline $\begin{array}{l}\text { Distrito } \\
\text { Federal }\end{array}$ & & Total & 1.305 & 1.497 & 1.560 & 545 & 988 & 504 & 40 & 49 & 1.612 & 8.100 \\
\hline & Retorno para a & Até 50 mil & 445 & 750 & 597 & 180 & 489 & 84 & 31 & 31 & 851 & 3.458 \\
\hline & Unidade da & 50 a 100 mil & 153 & 36 & 279 & 33 & 147 & 80 & 9 & 0 & 221 & 958 \\
\hline & Federação de & 100 a $500 \mathrm{mil}$ & 370 & 244 & 262 & 33 & 94 & 156 & 0 & 18 & 350 & 1.527 \\
\hline & nascimento & 500 mil a 1 milhão & 337 & 467 & 0 & 299 & 258 & 63 & 0 & 0 & 0 & 1.424 \\
\hline & & 1 milhão e mais & 0 & 0 & 422 & 0 & 0 & 121 & 0 & 0 & 190 & 733 \\
\hline & TOTAL & & 2.575 & 4.491 & 4.336 & 1.232 & 2.421 & 1.189 & 249 & 163 & 3.692 & 20.348 \\
\hline & & Total & 9.734 & 3.906 & 8.493 & 2.266 & 2.528 & 3.940 & 994 & 641 & 9.106 & 41.608 \\
\hline & & Até 50 mil & 5.092 & 2.587 & 4.552 & 1.459 & 1.677 & 1.786 & 518 & 384 & 5.005 & 23.060 \\
\hline & município de & 50 a $100 \mathrm{mil}$ & 1.688 & 114 & 1.227 & 110 & 196 & 800 & 108 & 103 & 1.722 & 6.068 \\
\hline & $\begin{array}{l}\text { municipio de } \\
\text { nascimento }\end{array}$ & 100 a 500 mil & 2.010 & 362 & 567 & 182 & 246 & 654 & 160 & 154 & 1.726 & 6.061 \\
\hline & & 500 mil a 1 milhão & 944 & 843 & 0 & 515 & 409 & 82 & 208 & 0 & 0 & 3.001 \\
\hline & & 1 milhão e mais & 0 & 0 & 2.147 & 0 & 0 & 618 & 0 & 0 & 653 & 3.418 \\
\hline $\begin{array}{l}\text { Uutros } \\
\text { Estados }\end{array}$ & & Total & 16.482 & 2.650 & 7.182 & 2.523 & 1.965 & 4.132 & 1.322 & 523 & 12.700 & 49.479 \\
\hline Estados & Retorno para a & Até 50 mil & 7.960 & 1.126 & 2.377 & 1.095 & 990 & 1.101 & 696 & 278 & 5.882 & 21.505 \\
\hline & Unidade da & 50 a $100 \mathrm{mil}$ & 3.462 & 263 & 912 & 254 & 170 & 671 & 123 & 118 & 2.355 & 8.328 \\
\hline & Federação de & 100 a 500 mil & 3.002 & 148 & 1.236 & 352 & 240 & 1.269 & 80 & 127 & 3.166 & 9.620 \\
\hline & nascimento & 500 mil a 1 milhão & 2.058 & 1.113 & 0 & 822 & 565 & 535 & 423 & 0 & 0 & 5.516 \\
\hline & & 1 milhão e mais & 0 & 0 & 2.657 & 0 & 0 & 556 & 0 & 0 & 1.297 & 4.510 \\
\hline & TOTAL & & 26.216 & 6.556 & 15.675 & 4.789 & 4.493 & 8.072 & 2.316 & 1.164 & 21.806 & 91.087 \\
\hline
\end{tabular}


Fonte: IBGE, Censo Demográfico 2000. Elaboração própria.

Tabela 2 - Nordeste: Migração de Retorno, por Município eUnidade da Federação de nascimento, por principais Estados de origem e Hierarquia de Cidades no destino - 2010

\begin{tabular}{|c|c|c|c|c|c|c|c|c|c|c|c|c|}
\hline \multirow{2}{*}{$\begin{array}{l}\text { Principais } \\
\text { UF's de } \\
\text { Origem }\end{array}$} & \multirow{2}{*}{$\begin{array}{l}\text { Migração de } \\
\text { retorno (tipo) }\end{array}$} & \multirow{2}{*}{$\begin{array}{c}\text { Hierarquia dos } \\
\text { municípios de } \\
\text { destino (hab.) }\end{array}$} & \multicolumn{9}{|c|}{ Unidades da Federação } & \multirow{2}{*}{ Total } \\
\hline & & & Maranhão & Piauí & Ceará & Rio Grande do Norte & Paraíba & Pernambuco & Alagoas & Sergipe & Bahia & \\
\hline \multirow{13}{*}{$\begin{array}{c}\text { Total } \\
\text { (Brasil) }\end{array}$} & \multirow{6}{*}{$\begin{array}{l}\text { Retorno para o } \\
\text { município de } \\
\text { nascimento }\end{array}$} & Total & 18.731 & 15.580 & 28.733 & 8.678 & 19.058 & 24.304 & 8.965 & 5.671 & 48.020 & 177.740 \\
\hline & & Até 50 mil & 8.191 & 10.112 & 15.011 & 4.471 & 12.568 & 11.197 & 4.821 & 2.701 & 28.467 & 97.539 \\
\hline & & 50 a 100 mil & 3.749 & 1.419 & 5.678 & 689 & 1.800 & 4.448 & 1.153 & 981 & 6.962 & 26.879 \\
\hline & & 100 a 500 mil & 4.276 & 1.316 & 2.686 & 740 & 2.359 & 3.915 & 698 & 127 & 7.851 & 23.968 \\
\hline & & 500 mil a 1 milhão & 0 & 2.733 & 0 & 2.778 & 2.331 & 958 & 2.293 & 1.862 & 1.083 & 14.038 \\
\hline & & 1 milhão e mais & 2.515 & 0 & 5.358 & 0 & 0 & 3.786 & 0 & 0 & 3.657 & 15.316 \\
\hline & \multirow{6}{*}{$\begin{array}{l}\text { Retorno para a } \\
\text { Unidade da } \\
\text { Federação de } \\
\text { nascimento }\end{array}$} & Total & 17.212 & 6.619 & 12.871 & 6.327 & 10.172 & 14.420 & 5.424 & 2.976 & 33.896 & 109.917 \\
\hline & & Até 50 mil & 8.350 & 3.252 & 4.591 & 2.035 & 4.326 & 4.951 & 2.620 & 972 & 15.596 & 46.693 \\
\hline & & 50 a 100 mil & 2.638 & 710 & 2.905 & 524 & 1.215 & 2.571 & 602 & 422 & 4.452 & 16.039 \\
\hline & & 100 a $500 \mathrm{mil}$ & 3.838 & 508 & 2.127 & 1.550 & 1.444 & 4.039 & 531 & 491 & 9.371 & 23.899 \\
\hline & & 500 mil a 1 milhão & 0 & 2.149 & 0 & 2.218 & 3.187 & 1.334 & 1.671 & 1.091 & 1.284 & 12.934 \\
\hline & & 1 milhão e mais & 2.386 & 0 & 3.248 & 0 & 0 & 1.525 & 0 & 0 & 3.193 & 10.352 \\
\hline & TOTAL & & 35.943 & 22.199 & 41.604 & 15.005 & 29.230 & 38.724 & 14.389 & 8.647 & 81.916 & 287.657 \\
\hline \multirow{13}{*}{ São Paulo } & & Total & 2.918 & 7.167 & 12.215 & 3.279 & 8.361 & 14.984 & 5.773 & 2.928 & 28.185 & 85.810 \\
\hline & & Até 50 mil & 1.266 & 5.146 & 6.597 & 2.163 & 6.088 & 8.237 & 3.415 & 1.821 & 18.622 & 53.355 \\
\hline & município de & 50 a 100 mil & 455 & 859 & 2.876 & 218 & 706 & 2.971 & 682 & 557 & 4.646 & 13.970 \\
\hline & nascimento & 100 a $500 \mathrm{mil}$ & 636 & 286 & 1.252 & 254 & 768 & 2.284 & 467 & 65 & 3.107 & 9.119 \\
\hline & & 500 mil a 1 milhão & 0 & 876 & 0 & 644 & 799 & 451 & 1.209 & 485 & 477 & 4.941 \\
\hline & & 1 milhão e mais & 561 & 0 & 1.490 & 0 & 0 & 1.041 & 0 & 0 & 1.333 & 4.425 \\
\hline & & Total & 1.922 & 2.577 & 5.707 & 2.425 & 4.141 & 9.073 & 3.439 & 1.484 & 18.115 & 48.883 \\
\hline & Retorno para a & Até 50 mil & 957 & 1.468 & 1.906 & 814 & 1.835 & 3.758 & 1.589 & 646 & 9.128 & 22.101 \\
\hline & Unidade da & 50 a 100 mil & 97 & 356 & 1.589 & 202 & 546 & 1.820 & 296 & 197 & 2.635 & 7.738 \\
\hline & Federação de & 100 a 500 mil & 440 & 47 & 1.022 & 726 & 575 & 2.227 & 395 & 193 & 4.204 & 9.829 \\
\hline & nascimento & 500 mil a 1 milhão & 0 & 706 & 0 & 683 & 1.185 & 721 & 1.159 & 448 & 617 & 5.519 \\
\hline & & 1 milhão e mais & 428 & 0 & 1.190 & 0 & 0 & 547 & 0 & 0 & 1.531 & 3.696 \\
\hline & TOTAL & & 4.840 & 9.744 & 17.922 & 5.704 & 12.502 & 24.057 & 9.212 & 4.412 & 46.300 & 134.693 \\
\hline & & Total & 1.165 & 811 & 5.110 & 2.187 & 6.595 & 2.346 & 633 & 660 & 3.748 & 23.255 \\
\hline & & Até 50 mil & 298 & 281 & 3.818 & 932 & 4.159 & 881 & 304 & 190 & 1.144 & 12.007 \\
\hline & $\begin{array}{l}\text { Ketorno para o } \\
\text { município de }\end{array}$ & 50 a $100 \mathrm{mil}$ & 177 & 91 & 360 & 161 & 723 & 261 & 91 & 152 & 334 & 2.350 \\
\hline & $\begin{array}{l}\text { municipio de } \\
\text { nascimento }\end{array}$ & 100 a $500 \mathrm{mil}$ & 174 & 193 & 187 & 43 & 873 & 333 & 60 & 19 & 943 & 2.825 \\
\hline & & 500 mil a 1 milhão & 0 & 246 & 0 & 1.051 & 840 & 0 & 178 & 299 & 201 & 2.815 \\
\hline & & 1 milhão e mais & 516 & 0 & 745 & 0 & 0 & 871 & 0 & 0 & 1.126 & 3.258 \\
\hline Janeiro & & Total & 614 & 252 & 2.295 & 1.397 & 3.351 & 1.308 & 347 & 643 & 2.540 & 12.747 \\
\hline & Retorno para a & Até 50 mil & 154 & 85 & 1.407 & 445 & 1.594 & 264 & 78 & 112 & 852 & 4.991 \\
\hline & Unidade da & 50 a 100 mil & 92 & 20 & 158 & 139 & 419 & 207 & 94 & 58 & 180 & 1.367 \\
\hline & Federação de & 100 a $500 \mathrm{mil}$ & 148 & 21 & 270 & 131 & 477 & 502 & 33 & 101 & 917 & 2.600 \\
\hline & nascimento & 500 mil a 1 milhão & 0 & 126 & 0 & 682 & 861 & 159 & 142 & 372 & 178 & 2.520 \\
\hline & & 1 milhão e mais & 220 & 0 & 460 & 0 & 0 & 176 & 0 & 0 & 413 & 1.269 \\
\hline & TOTAL & & 1.779 & 1.063 & 7.405 & 3.584 & 9.946 & 3.654 & 980 & 1.303 & 6.288 & 36.002 \\
\hline & & Total & 2.413 & 3.169 & 2.130 & 458 & 1.003 & 943 & 193 & 310 & 2.471 & 13.090 \\
\hline & & Até 50 mil & 944 & 2.146 & 845 & 257 & 704 & 173 & 24 & 45 & 1.674 & 6.812 \\
\hline & $\begin{array}{l}\text { Retorno para o } \\
\text { município de }\end{array}$ & 50 a 100 mil & 474 & 213 & 511 & 0 & 30 & 193 & 36 & 0 & 207 & 1.664 \\
\hline & $\begin{array}{c}\text { municipio de } \\
\text { nascimento }\end{array}$ & 100 a 500 mil & 571 & 384 & 296 & 36 & 174 & 33 & 7 & 0 & 397 & 1.898 \\
\hline & & 500 mil a 1 milhão & 0 & 426 & 0 & 165 & 95 & 159 & 126 & 265 & 55 & 1.291 \\
\hline & & 1 milhão e mais & 424 & 0 & 478 & 0 & 0 & 385 & 0 & 0 & 138 & 1.425 \\
\hline Federal & & Total & 1.312 & 1.508 & 910 & 417 & 694 & 529 & 55 & 71 & 1.542 & 7.038 \\
\hline & Retorno para a & Até 50 mil & 468 & 912 & 231 & 132 & 258 & 119 & 0 & 27 & 743 & 2.890 \\
\hline & Unidade da & 50 a 100 mil & 184 & 114 & 231 & 27 & 78 & 57 & 0 & 0 & 151 & 842 \\
\hline & Federação de & 100 a $500 \mathrm{mil}$ & 343 & 205 & 171 & 74 & 35 & 171 & 0 & 18 & 538 & 1.555 \\
\hline & nascimento & 500 mil a 1 milhão & 0 & 277 & 0 & 184 & 323 & 82 & 55 & 26 & 0 & 947 \\
\hline & & 1 milhão e mais & 317 & 0 & 277 & 0 & 0 & 100 & 0 & 0 & 110 & 804 \\
\hline & TOTAL & & 3.725 & 4.677 & 3.040 & 875 & 1.697 & 1.472 & 248 & 381 & 4.013 & 20.128 \\
\hline & & Total & 12.235 & 4.433 & 9.278 & 2.754 & 3.099 & 6.031 & 2.366 & 1.773 & 13.616 & 55.585 \\
\hline & & Até 50 mil & 5.683 & 2.539 & 3.751 & 1.119 & 1.617 & 1.906 & 1.078 & 645 & 7.027 & 25.365 \\
\hline & $\begin{array}{l}\text { Retorno para o } \\
\text { município de }\end{array}$ & 50 a 100 mil & 2.643 & 256 & 1.931 & 310 & 341 & 1.023 & 344 & 272 & 1.775 & 8.895 \\
\hline & & 100 a 500 mil & 2.895 & 453 & 951 & 407 & 544 & 1.265 & 164 & 43 & 3.404 & 10.126 \\
\hline & & 500 mil a 1 milhão & 0 & 1.185 & 0 & 918 & 597 & 348 & 780 & 813 & 350 & 4.991 \\
\hline & & 1 milhão e mais & 1.014 & 0 & 2.645 & 0 & 0 & 1.489 & 0 & 0 & 1.060 & 6.208 \\
\hline $\begin{array}{l}\text { Outros } \\
\text { Estados }\end{array}$ & & Total & 13.364 & 2.282 & 3.959 & 2.088 & 1.986 & 3.510 & 1.583 & 778 & 11.699 & 41.249 \\
\hline & Retorno para a & Até 50 mil & 6.771 & 787 & 1.047 & 644 & 639 & 810 & 953 & 187 & 4.873 & 16.711 \\
\hline & Unidade da & 50 a 100 mil & 2.265 & 220 & 927 & 156 & 172 & 487 & 212 & 167 & 1.486 & 6.092 \\
\hline & Federação de & 100 a 500 mil & 2.907 & 235 & 664 & 619 & 357 & 1.139 & 103 & 179 & 3.712 & 9.915 \\
\hline & nascimento & 500 mil a 1 milhão & 0 & 1.040 & 0 & 669 & 818 & 372 & 315 & 245 & 489 & 3.948 \\
\hline & & 1 milhão e mais & 1.421 & 0 & 1.321 & 0 & 0 & 702 & 0 & 0 & 1.139 & 4.583 \\
\hline & TOTAL & & 25.599 & 6.715 & 13.237 & 4.842 & 5.085 & 9.541 & 3.949 & 2.551 & 25.315 & 96.834 \\
\hline
\end{tabular}

Fonte: IBGE, Censo Demográfico 2010. Elaboração própria. 